\title{
Water Quality Profile of Yamuna River, India
}

\author{
M.P. Sharma, S.K. Singal and S. Patra
}

\begin{abstract}
The water quality profile of a river represents the extent of its pollution in terms of health of a river with respect to its longitudinal direction. This paper deals with the water quality profile of north India's Yamuna river using physico-chemical and bacteriological parameters that converge into a single value NSF WQI. The water quality map of the river has been prepared showing that the Delhi stretch is highly polluted due to dumping of waste and discharge of untreated sewage and industrial effluents. The water quality map is a useful tool for policy makers, decision makers and environmentalists to suggest and implement appropriate conservation measures to improve the health of the water body.
\end{abstract}

Key words: Water quality, pollution, river profile, indices, mapping, India

\section{Introduction}

R ivers are important resources for human Rcivilizations as they meet water demand for various uses apart from supporting flora and fauna, improving aesthetic and landscape quality, moderating climate and providing resource for hydropower. The upper reaches of the yamuna river are found to have good quality of water because of less human impacts but as it passes through semi urban to urban areas, it starts receiving pollution due to various point and non-point sources of pollution as a result of anthropogenic activities. River flow is highly variable with respect to climatic situation and drainage pattern. Vertical mixing is achieved due to prevailing current and turbulence. Urbanization and industrialization are built up near rivers in order to draw water for various uses, but as a result wastewater is often released without proper treatment resulting in heavy river pollution.

The river profile can be used as a tool to determine water quality at various locations based on inputs of pollutants being received by the water body. Accordingly, the river can be assigned as kilometer stone, starting from its source to ultimate confluence. The features that should be assigned $\mathrm{km}$ stones along the length of a river are: (1) sampling stations, (2) points of confluence of tributaries (or points of confluence of sub-tributaries in case of tributaries), (3) cities/towns and (4) waste water or effluent outfalls meeting the river.

Assessment of river quality consists of following:

- Assigning dissolved oxygen (DO), biochemical oxygen demand (BOD), fecal coliform (FC), total coliform (TC) or any other pollutant's profiles with respect to actual distances between consecutive sampling stations and interpretation of rivermonitoring data.

- Assessment of profile of entire length and profile of polluted length of river.

- Identification of pollution sources (point as well as nonpoint) in a given stretch.
- Monitoring of river profile after implementation of conservation or mitigation measures, providing large sets of information for digitization with the help of Geographical Information System (GIS).

- Converge all parameters into a single value index which can be used to prepare a water quality map, which will be helpful for planners, decision or policy makers for mitigation action at the governmental level.

\section{Literature review}

The riverine resources of India contain 113 river basins out of which 14 are major, 44 medium and remaining 55 are minor rivers (Kumar, A. 2002). The 14 major river basin accounts for $83 \%$ of the total area of the basin and contributes $85 \%$ of the total surface flow and covers $80 \%$ of the total length (Chaudhuri 1982).

Lots of research has been carried out by different authors in assessing the water quality profile of rivers using different pollution stress parameters (Haslam 1991, Gopal and Agarwal 2003, Rajvaidya 2005, Trivedy 2000). The pollution profile of the Periyar river in Kerala, subjected to heavy industrial load, was studied with general parameters as well as heavy metals for its surface water as well as bed sediment (Paul and Pillai 1978). The pollution profile of the Damodar river in the industrial and coal mining stretches has been studied several times (De, Sen and Karim 1985, Singh and Gupta 2000). Yamuna river pollution has been described taking simple parameters viz. coliform, DO \& BOD (Kumar, V. 2002).

The major tool of pollution profile studies is the water quality index (WQI). Horton proposed the first formal WQI in the literature in 1965 (Ott 1978). After that a convenient WQI was formulated based on expert opinion (Brown et al 1970). It has been accepted by National Sanitation Foundation (NSF), USA, and is widely used in many countries (Ott 1978). Presently, Wilkes University in the USA facilitates a simple on 
line calculator for the NSF WQI using nine WQ parameters (WU 2008).

The first reported Indian WQI was suggested for zoning and classification of river Ganga with respect to specific issue of drinking water supply. It was suggested that the public drinking water supplies should have a WQI higher than 90 (Bhargava 1985). In 1990, Ved Prakash formulated a River Ganga Index based on the Brown's NSF WQI with slight modifications in terms of weightages to conform to the water quality criteria for different categories of uses as set by Central Pollution Control Board (CPCB), India (Abbasi 2002). An overall index of pollution for surface water based on average value of all the pollution sub indices gives a general classification scheme in the Indian context (Sargoankat and Deshpande 2003).

\section{Water quality parameters}

The following water quality parameters are considered in order to determine pollution status of a river:

\section{Physical parameters}

(i) $\mathrm{pH}$, (ii) temperature, (iii) turbidity, (iv) TSS, (v) TDS, (vi) color, taste and odor, and (vii), electrical conductivity, etc.

\section{Chemical parameters}

(a) Inorganic waste: (i) inert suspension, (ii) inorganic salts (e.g. $\mathrm{Ca}, \mathrm{Mg}$ as $\mathrm{CaCO}_{3}$ ), (iii) acids and alkalis, (iv) fertilizers, (v) toxic metals (As, $\mathrm{Cd}, \mathrm{Pb}, \mathrm{Zn}$, $\mathrm{Co}, \mathrm{Cu}, \mathrm{Cr}, \mathrm{Fe}, \mathrm{Ni}$ ), (vi) inorganic salts, (vii) oxides, and (viii) radioactive waste; and (b) Organic waste: (i) sewage (DO, BOD, COD), (ii) oils and grease, (iii) detergents, (iv) pesticides, and (v) nutrients (nitrogen and phosphorus), etc.

\section{Biological parameters}

(i) pathogens (total coliform \& fecal coliform), (ii) algal toxins, and (iii) toxic products due to microbial activity, etc.

\section{Pollution Stresses}

Two general categories, direct and indirect contaminant sources, are available. Direct sources include effluent outfalls from factories, refineries, waste water treatment plants, etc., which directly leak into urban water supplies; while the later includes contaminants that enter the river from soils/ groundwater and from the atmosphere through rain. Soils and groundwater contain the residue of domestic wastes, agricultural wastes (fertilizers, pesticides, etc.) and improperly disposed off industrial wastes. 2005)
The pollution potential in the Yamuna catchment area depends on various human activities and is categorized into two groups: (a) point sources of pollution-domestic sewage and industrial effluence, and (b) non point sources of pollution-agricultural runoff, in-stream water uses, bathing, cattle wading, open defecation and clothes washing (after YAP 2008). In addition, other sources of river pollution are soil erosion, atmospheric fall out of pollutants, accidental cases of shipment, and river damming effects. Table 1 classifies the major types of water pollutants.

\begin{tabular}{|c|c|c|}
\hline & Types & Examples \\
\hline$\overline{1 .}$ & oxygen demanding wastes & $\begin{array}{l}\text { human and animal waste, decaying } \\
\text { vegetation }\end{array}$ \\
\hline 2. & plant nutrients & nitrates and phosphates \\
\hline 3. & infectious agents & bacteria, virus, protozoa, fungi \\
\hline 4. & organic matters & oil, detergents, pesticides, etc. \\
\hline 5. & inorganic metals \& chemicals & acids, heavy and toxic metals \\
\hline 6. & priority pollutants & $\begin{array}{l}\text { DDT (organic chlorine), PCBs } \\
\text { (polychlorinated biphenyl), persistent } \\
\text { organic pollutants (dioxin and furan) }\end{array}$ \\
\hline 7 & heat & used water from cooling in industries \\
\hline 8. & radioactive substances & fallout products, radioactive wastes \\
\hline
\end{tabular}

Table 1: Classification of major water pollutants (modified after Sharma

\section{Assessment of River Water Quality}

\section{Sampling procedure}

Conventional sampling methods are based on a bottle collection or water pump system and use a boat if sampling is not possible from a bridge. After the homogeneity of water quality is established in the cross-section of the river, samples from the river at fairly deep locations can be done. A depth integrated sample can be obtained by hauling the pump inlet through desired depths and allowing pump to continue for a fixed time interval at each depth. Pumps can be used to collect a series of depth integrated samples across a river for large volume samples. For selective variables, e.g., $\mathrm{DO}, \mathrm{pH}$, conductivity and turbidity, submersible probes can also be used. For sediment sampling, filtration is normally done with 0.25ìm and 0.45ìm filters followed by centrifugation (Chapman 1996).

\section{Method for calculation of water quality index}

An index is a mean device to reduce a large quantity of data down to a simplest form (Ott 1978). The water quality indices help to evaluate the water quality profile of a river in its entire stretch and to identify the reaches where the gap between the desired and the existing water quality is significant enough to warrant urgent pollution control measures. In India 
the NSF WQI is being used by CPCB, with a slight modification in weights (Abbasi 2002, CPCB 2001).

The NSF WQI is expressed mathematically as: NSFWQI $=O_{\mathrm{P}}$ WiIi, where $\mathrm{Ii}=$ sub index for $\mathrm{i}^{\text {th }}$ water quality parameter, $\mathrm{Wi}=$ weight (in terms of importance) associated with water quality parameter, and $\mathrm{P}=$ number of water quality parameters. The modified weights (Wi) and the equation for the sub indices (Ii) as per CPCB, are given in Table 2 and 3, respectively. The range of the NSF WQI corresponding to various designated best use classification is given in Table 4 .

Sequential steps for whole pollution profile study are shown as a flow diagram in Figure 1.

\begin{tabular}{lll}
\hline $\begin{array}{l}\text { Water Quality } \\
\text { Parameters }\end{array}$ & $\begin{array}{l}\text { Original Weights } \\
\text { from NSF WQI }\end{array}$ & $\begin{array}{l}\text { Modified Weights } \\
\text { by CPCB }\end{array}$ \\
\hline DO & 0.17 & 0.31 \\
Fecal Coliforms & 0.15 & 0.28 \\
pH & 0.12 & 0.22 \\
BOD & 0.1 & 0.19 \\
Total & 0.54 & 1.00 \\
\hline
\end{tabular}

Table 2: Original and Modified Weights for the computation of NSF WQI based on DO, Fecal Coliforms, $\mathrm{pH}$ and BOD (CPCB 2001)

\begin{tabular}{|c|c|c|}
\hline Water Quality Parameters & Range Applicable & Equation \\
\hline DO ( Percent Saturation) & $\begin{array}{l}0-40 \% \text { saturation } 40+-100 \% \\
\text { saturation } 100+-140 \% \\
\text { saturation> } 140 \% \text { saturation }\end{array}$ & $\begin{array}{l}\text { IDO }=0.18+0.66 \times(\% \text { sat DO }) \\
\text { IDO }=-13.55+1.17 X(\% \text { sat DO }) \\
\text { IDO }=163.34-0.62 X(\% \text { sat DO }) \\
\text { IDO }=50\end{array}$ \\
\hline $\mathrm{BOD}(\mathrm{mg} / \mathrm{l})$ & $\begin{array}{l}0-10 \\
10+-30 \\
>30\end{array}$ & $\begin{array}{l}\mathrm{IBOD}=96.67-7.0 \times(\mathrm{BOD}) \\
\mathrm{IBOD}=38.9-1.23 \times(\mathrm{BOD}) \\
\mathrm{IBOD}=2\end{array}$ \\
\hline $\mathrm{pH}$ & $\begin{array}{l}2-5 \\
5+-7.3 \\
7.3+-10 \\
10+-12 \\
<2 \text { or }>12\end{array}$ & $\begin{array}{l}\mathrm{IpH}=16.1+7.35 \times(\mathrm{pH}) \\
\mathrm{IpH}=-142.67+33.5 X(\mathrm{pH}) \\
\mathrm{IpH}=316.96-29.85 \times(\mathrm{pH}) \\
\mathrm{IpH}=96.17-8.0 \times(\mathrm{pH}) \\
\mathrm{IpH}=0\end{array}$ \\
\hline $\begin{array}{l}\text { Fecal Coliforms (FC) } \\
\text { (CFU/100ml) }\end{array}$ & $\begin{array}{l}1-103 \\
103-105 \\
>105\end{array}$ & $\begin{array}{l}\mathrm{IFC}=97.2-26.6 \log (\mathrm{FC}) \\
\mathrm{IFC}=42.33-7.75 \log (\mathrm{FC}) \\
\mathrm{IFC}=2\end{array}$ \\
\hline
\end{tabular}

Table 3: Sub index Equations for Water Quality Parameters (NSF WQI) (based on Abbasi 2002)

\begin{tabular}{llllll}
\hline & NSF WQI & Description & Class & Color Code & Remarks \\
\hline 1. & $63-100$ & Good to Excellent & A & Blue & Non polluted \\
2. $51-63$ & Medium to Good & B & Green & Non polluted \\
3. $\quad 38-50$ & Bad & C & Yellow & Polluted \\
4. $\quad<38$ & Bad to very bad & D or E & Red & Heavily polluted \\
\hline
\end{tabular}

Table 4: NSF WQI for various designated-best-use (CPCB 2001)

\section{Case study on the Yamuna River, India}

The river Yamuna is the main tributary of Ganga River having length of $1,376 \mathrm{~km}$. About 57 million people of north India depend on it. Its annual flow is about 10,000 cusecs and accounts for more than $70 \%$ of Delhi's overall water supply. Available water treatment facilities are not adequate to remove all the pollutants. Consequently, the Yamuna leaves Delhi as a sewer, laden with the city's biological and chemical wastes. Downstream, at Agra, this becomes the main municipal drinking water source. Here, too, the existing treatment facilities are inadequate to treat the pollutants. Thus, consumers in Delhi and Agra ingest unknown amounts of toxic pesticide residues each time they drink water (CSE 2008).

CPCB has been regularly monitoring the entire stretch of the Yamuna river under the National River Conservation Program (NRCR) and National Water Quality Monitoring Program (NWQMP). Monitoring was done at 19 sampling locations in five stretches from the origin of Yamuna River at Yamunotri to its confluence with Ganga River at Allahabad (CPCB 2008). The water quality parameters in various stretches in 2004 are given in Table 5. The NSF WQI was applied after conversion for DO and coliform (Gronewold and Wolpert 2008). The class category and pollution profile map are shown in the Figures 2 and 3, respectively.

Water quality status at river Yamuna during the year 2004 reflects that the Delhi stretch is severely polluted as compared to the other stretches. The total coliform in the entire river stretch is significantly high and generally does not conform to designated water quality criteria. BOD in the Himalayan stretch remains within limit of $3 \mathrm{mg} /$ l, due to less an thropogenic activities while at upper and diluted stretches, the BOD level is almost within the limit. In Delhi and mixed stretches the BOD values remain above the limit because of heavy sewage discharge and less flow, after which the river recovers itself in the 


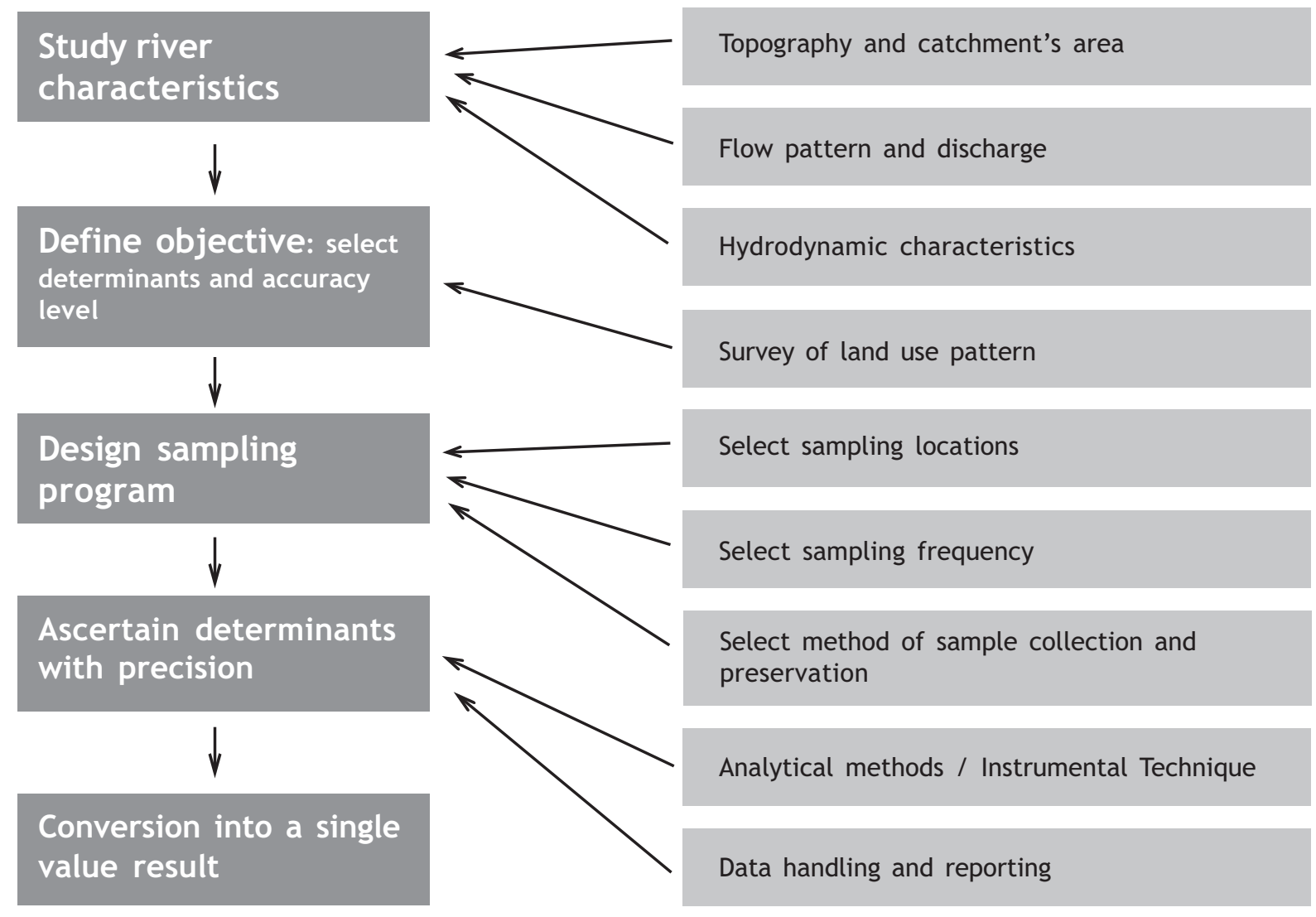

Figure 1: Flow Chart of Overall Procedure (modified after NEERI 1986)

\begin{tabular}{|c|c|c|c|c|c|c|c|c|}
\hline & $\begin{array}{l}\text { River } \\
\text { Stretch }\end{array}$ & Stretch details & $\begin{array}{l}\text { Trophic } \\
\text { status }\end{array}$ & Value & $\mathrm{pH}$ & $\begin{array}{l}\mathrm{DO} \\
\mathrm{mg} / \mathrm{l}\end{array}$ & $\begin{array}{l}\text { BOD } \\
\mathrm{mg} / \mathrm{l}\end{array}$ & $\begin{array}{l}\text { Fecal } \\
\text { Coliform } \\
\text { CFU/100 ml }\end{array}$ \\
\hline \multirow[t]{3}{*}{1.} & \multirow{3}{*}{$\begin{array}{l}\text { Himalayan } \\
\text { Stretch }\end{array}$} & \multirow{3}{*}{$\begin{array}{l}172 \mathrm{~km} \text { from origin } \\
\text { to Hathnikund } \\
\text { barrage }\end{array}$} & \multirow[t]{3}{*}{ Oligotrophic } & Min & 6.83 & 7.2 & 1 & 70 \\
\hline & & & & Max & 8.89 & 10.8 & 3 & 10200 \\
\hline & & & & Avg & - & 9.2 & 1 & 2448 \\
\hline \multirow[t]{3}{*}{2.} & \multirow{3}{*}{$\begin{array}{l}\text { Upper } \\
\text { stretch }\end{array}$} & \multirow{3}{*}{$\begin{array}{l}224 \mathrm{~km} \text { from } \\
\text { Hathnikund barrage } \\
\text { to Wazirabad } \\
\text { barrage }\end{array}$} & \multirow[t]{3}{*}{ Mesotrophic } & Min & 7.03 & 6.3 & 1 & 140 \\
\hline & & & & $\operatorname{Max}$ & 8.91 & 10.7 & 8 & 139000 \\
\hline & & & & Avg & - & 8.1 & 3 & 16557 \\
\hline \multirow[t]{3}{*}{3.} & \multirow{3}{*}{$\begin{array}{l}\text { Delhi } \\
\text { stretch }\end{array}$} & \multirow{3}{*}{$\begin{array}{l}22 \mathrm{~km} \text { from } \\
\text { Wazirabad barrage } \\
\text { to Okhla barrage }\end{array}$} & \multirow[t]{3}{*}{ Septic } & Min & 7.09 & 0.0 & 6 & 160000 \\
\hline & & & & $\operatorname{Max}$ & 8.82 & 1.4 & 49 & 46000000 \\
\hline & & & & Avg & - & 0.1 & 22.8 & 7267917 \\
\hline \multirow[t]{3}{*}{4.} & \multirow{3}{*}{$\begin{array}{l}\text { Mixed } \\
\text { stretch }\end{array}$} & \multirow{3}{*}{$\begin{array}{l}330 \mathrm{~km} \text { Okhla } \\
\text { barrage to river } \\
\text { Chambal } \\
\text { confluence }\end{array}$} & \multirow{3}{*}{$\begin{array}{l}\text { Mesotrophic/ } \\
\text { Eutrophic/ } \\
\text { Septic }\end{array}$} & Min & 7.24 & 0.0 & 3 & 1800 \\
\hline & & & & $\operatorname{Max}$ & 9.04 & 19.5 & 40 & 47000000 \\
\hline & & & & $\mathrm{Av}$ & - & 7.4 & 12 & 1813017 \\
\hline 5. & $\begin{array}{l}\text { Diluted } \\
\text { stretch }\end{array}$ & $\begin{array}{l}628 \mathrm{~km} \text { River } \\
\text { Chambal } \\
\text { confluence to river } \\
\text { Ganga confluence }\end{array}$ & $\begin{array}{l}\text { Mesotrophic/ } \\
\text { Eutrophic }\end{array}$ & Min & 7.40 & 5.7 & 2 & 1700 \\
\hline
\end{tabular}

Table 5: Water Quality Characteristics of Various Segment/Stretches of River Yamuna in 2004 (CPCB 2008) 


\begin{tabular}{|c|c|c|c|c|c|c|c|c|}
\hline & $\begin{array}{l}\text { River } \\
\text { Stretch }\end{array}$ & Stretch details & $\begin{array}{l}\text { Trophic } \\
\text { status }\end{array}$ & Value & $\mathrm{pH}$ & $\begin{array}{l}\mathrm{DO} \\
\mathrm{mg} / \mathrm{l}\end{array}$ & $\begin{array}{l}\text { BOD } \\
\mathrm{mg} / \mathrm{l}\end{array}$ & $\begin{array}{l}\text { Fecal } \\
\text { Coliform } \\
\text { CFU/100 ml }\end{array}$ \\
\hline \multirow[t]{3}{*}{1.} & \multirow{3}{*}{$\begin{array}{l}\text { Himalayan } \\
\text { Stretch }\end{array}$} & \multirow{3}{*}{$\begin{array}{l}172 \mathrm{~km} \text { from origin } \\
\text { to Hathnikund } \\
\text { barrage }\end{array}$} & \multirow[t]{3}{*}{ Oligotrophic } & Min & 6.83 & 7.2 & 1 & 70 \\
\hline & & & & Max & 8.89 & 10.8 & 3 & 10200 \\
\hline & & & & Avg & - & 9.2 & 1 & 2448 \\
\hline \multirow[t]{3}{*}{2.} & \multirow{3}{*}{$\begin{array}{l}\text { Upper } \\
\text { stretch }\end{array}$} & \multirow{3}{*}{$\begin{array}{l}224 \mathrm{~km} \text { from } \\
\text { Hathnikund barrage } \\
\text { to Wazirabad } \\
\text { barrage }\end{array}$} & \multirow[t]{3}{*}{ Mesotrophic } & Min & 7.03 & 6.3 & 1 & 140 \\
\hline & & & & Max & 8.91 & 10.7 & 8 & 139000 \\
\hline & & & & Avg & - & 8.1 & 3 & 16557 \\
\hline \multirow[t]{3}{*}{3.} & \multirow{3}{*}{$\begin{array}{l}\text { Delhi } \\
\text { stretch }\end{array}$} & \multirow{3}{*}{$\begin{array}{l}22 \mathrm{~km} \text { from } \\
\text { Wazirabad barrage } \\
\text { to Okhla barrage }\end{array}$} & \multirow[t]{3}{*}{ Septic } & Min & 7.09 & 0.0 & 6 & 160000 \\
\hline & & & & Max & 8.82 & 1.4 & 49 & 46000000 \\
\hline & & & & Avg & - & 0.1 & 22.8 & 7267917 \\
\hline \multirow[t]{3}{*}{4.} & \multirow{3}{*}{$\begin{array}{l}\text { Mixed } \\
\text { stretch }\end{array}$} & \multirow{3}{*}{$\begin{array}{l}330 \mathrm{~km} \text { Okhla } \\
\text { barrage to river } \\
\text { Chambal } \\
\text { confluence }\end{array}$} & \multirow{3}{*}{$\begin{array}{l}\text { Mesotrophic/ } \\
\text { Eutrophic/ } \\
\text { Septic }\end{array}$} & Min & 7.24 & 0.0 & 3 & 1800 \\
\hline & & & & Max & 9.04 & 19.5 & 40 & 47000000 \\
\hline & & & & AV & - & 7.4 & 12 & 1813017 \\
\hline 5. & $\begin{array}{l}\text { Diluted } \\
\text { stretch }\end{array}$ & $\begin{array}{l}628 \mathrm{~km} \text { River } \\
\text { Chambal } \\
\text { confluence to river } \\
\text { Ganga confluence }\end{array}$ & $\begin{array}{l}\text { Mesotrophic/ } \\
\text { Eutrophic }\end{array}$ & Min & 7.40 & 5.7 & 2 & 1700 \\
\hline
\end{tabular}

Figure 2: Class Category of Yamuna River

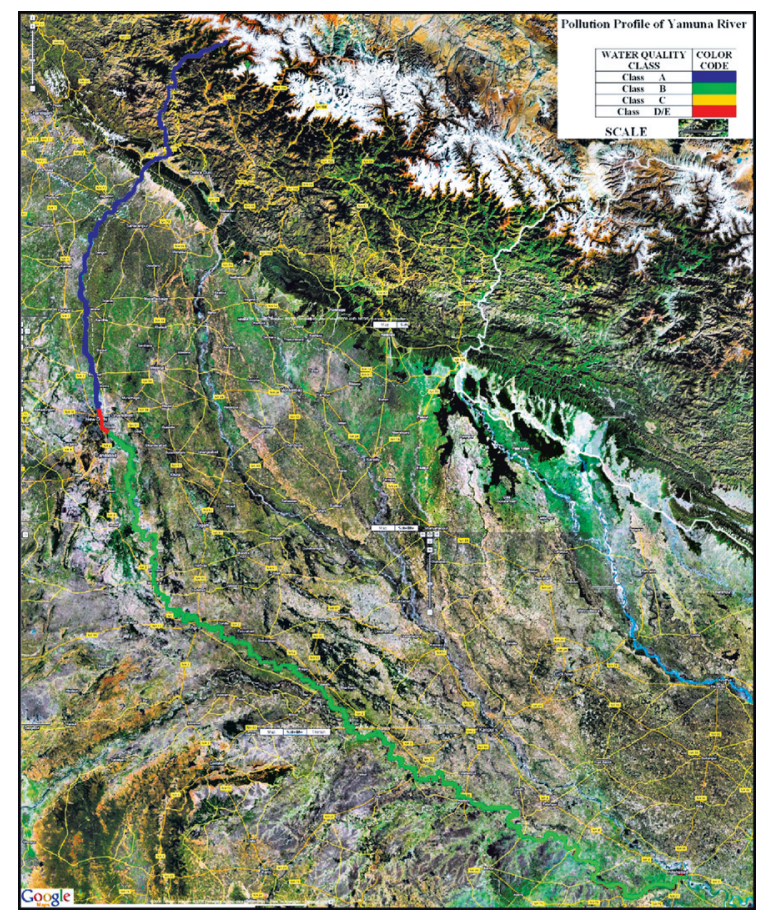

Figure 3: Water Quality Profile of Yamuna River in 2004 (based on Google map 2008)

next stretches due to less pollution input and augmentation in discharges. This happens due to self purification action of river.

The trend of coliform levels indicates decrease in total coliforms and increase in fecal coliforms in Himalayan, upper and diluted stretch; whereas the coliform trend is reversed in the Delhi stretch; i.e., an increase in total coliforms and decrease in fecal coliforms. A declining trend of coliforms is observed in mixed stretches.

\section{Long term impact and control of pollution of the rivers}

The historic evolution of water pollution control is shown schematically in Figure 4, which illustrates the deterioration of water quality without any control (A-B) and accelerates pollution due to industrialization (B-C). If public concern starts early (point B), it takes some time (BC) for the relevant authorities to initiate control measures. If the measures are insufficient, the rate of increase in pollution is lowered (C-D2), but if the economic activity is still growing, or if the assimilation capacity of the environment (storage, dilution, self purification) is limited, the pollution rapidly reaches the threshold concentration (C-D1) where severe or irreversible damages occurs. If proper action is taken, the pollution reaches a maximum (E) after a time-lag (CE) which depends on the effectiveness of the control, on the water residence time and on the pollutant interaction. Finally, a tolerable environmental level (F) may eventually be reached, although this is not equivalent to the pristine level (O). Four phases of environmental problem development (I-IV) are applicable for different types of pollution problems with different level of socioeconomic development (adapted from Chapman 1996).

\section{River conservation strategies}

- Treatment technologies like sewage treatments plants, industrial effluent treatment plants and solid waste management.

- Non-technical aspects like low cost sanitation and decentralized sanitation systems, electric and improved crematoria, bathing ghats/ river front developments, plantation and landscaping, public participation and awareness program.

- Enforcement of the Water (Prevention and Control of Pollution) Act, 1974, and other relevant environmental protection acts.

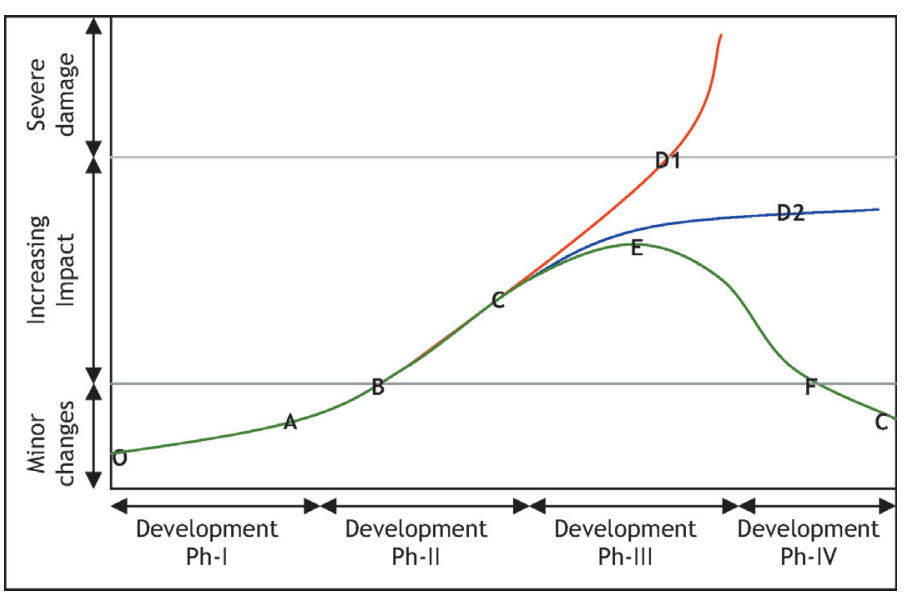

Figure 4: Long Term Impact and Control of Pollution (Chapman 1996) 


\section{Conclusion}

Present study concerns only the four water quality parameters that give conservative results. For detailed status of the river each and every pollution stress should be monitored. As we see that the Yamuna in the Delhi stretch has become almost dead and not suitable for any type of designated uses. Immediate restoration should be done there. Sufficient time and flow is needed for self purification of the stretch. Input of pollution load should be minimized. One suggestion for these is the channelization of all point source inlets towards the stretch after Delhi. 'Control, not prohibition' is the keyword. It is unrealistic to prohibit discharges to water bodies. The careful, diligent control of discharges to rivers will go a long way towards restoring and preserving the good quality of water.

M.P. Sharma is Associate Professor at the Alternate Hydro Energy Center, Indian Institute of Technology, Roorkee. S.K. Singal is a Senior Scientific Officer and S. Patra is an $M$. Tech at the same center.

Corresponding address: mpshafah@iitr.ernet.in.

\section{End notes}

1. The present paper deals with assessment of the water profile of Yamuna River as a case study considering four major water quality parameters; viz., DO, BOD, pH \& FC monitored by the Central Pollution Control Board (CPCB), India. These are converted into a single number i.e. water quality index (WQI) using a method developed by National Sanitation Foundation (NSF), USA and modified by CPCB, India. Finally NSF WQI has been used to prepare a water quality map of the river stretch.

\section{References}

Abbasi, S.A., 2002, Water Quality Indices State-of-theArt, Pondicherry: Pondicherry University, Centre for Pollution Control \& Energy Technology.

Bhargava, D.S. 1985, 'Expression for Drinking Water Supply Standards', ASCE, 111(3):304-317

Brown, Robert M., N.I. McClelland, R.A., Deininger and G.T. Ronald, 1970, 'A Water Quality Index: Do we dare?', Water Sewage Works, 339-349.

Chapman, D., 1996, Water Quality Assessment: A guide to the Use of Biota, Sediment and Water in Environmental Monitoring, Madras: E\&F N Spon.

Chaudhuri, N., 1982, Water and Air Quality Control, The Indian Context, New Delhi: Central Board for the Prevention and Control of Water Pollution.

CPCB, 2001, Environmental Atlas of India, New Delhi: Central Pollution Control Board.
CPCB, 2008, Annual Report 2004-2005, New Delhi: Central Pollution Control Board. URL: http:// cpcb.nic.in/oldwebsite/annualreporto4-05/ar2004ch5.htm.

CPCB and Survey of India, 1994, Water Quality Atlas of India, New Delhi: Central Pollution Control Board.

CSE, 2008, River Yamuna, New Delhi: Centre for Science and Environment. URL: www.rainwaterharvesting.org/Crisis / Riveryamuna.htm

De, A.K., A.K. Sen, and Md. Karim R., 1985, 'Pollution profile of Damodar river sediment in Raniganj, Durgapur industrial belt, West Bengal', Environment International (USA) 11.

Google map, 2008. URL: www. maps.google.com

Gopal, K. and A.K. Agarwal, 2003, River Pollution in India and Its Management, New Delhi: APH Publishing.

Gronewold, A. D. and R.L. Wolpert, 2008, Modeling the Relationship Between Most Probable Number (MPN) and Colony-Forming Unit (CFU) Estimates of Fecal Coliform Concentration, Durham, NC (USA): Duke University.

Haslam, S.M., 1991, River Pollution-An Ecological Perspective, New Delhi: CBS Publishers.

Kumar, A., 2002, Ecology of Polluted Waters, 2 (1st ed.), New Delhi: APH Publishing.

Kumar, V., 2002, 'Water pollution of Yamuna', Nistads News, 38, 4 (2).

NEERI, 1986, A Laboratory Manual, Nagpur: National Environmental Engineering and Research Institute.

Ott, W.R., 1978. Environmental Indices: Theory and Practice, Ann Arbor, MI (USA): Science Publishers Inc.

Paul, A.C. and K.C. Pillai, 1978, 'Pollution profile of a river', Journal of Water, Air and Soil Pollution 10 (2).

Rajvaidya, N. and D. Markandey, 2005, Environmental Pollution Control, New Delhi: APH Publishing.

Sargoankat, A. and V. Deshpande, 2003, 'Development of an overall index of pollution for surface water based on a general classification scheme in Indian context', Journal of Environmental Monitoring and Assessment, 83.

Sharma, B.K., 2005, Environmental Chemistry, Meerut: GOEL Publishing House

Singh, G and V.K. Gupta, 2000, 'A Pollution profile of Damodar river', Pollution and Biomonitoring of Indian Rivers, Jaipur: ADB Publishers.

Trivedy, R.K., 2000, Pollution and Biomonitoring of Indian Rivers, Jaipur: ADB Publishers.

WU, 2008, Calculating NSF Water Quality Index, WilkesBarre, PA (USA): Wilkes University, Center for Environmental Quality Environmental Engineering and Earth Sciences. URL: www.water-research.net/ watrqualindex/index.htm.

YAP, 2008, 'Pollution Potential in the Yamuna Basin', Yamuna Action Plan. URL: http://yap.nic.in/ pollution-cause1.asp. 